\title{
Crossing the bridge: Notes on the development of the rynd
}

\author{
Martin Watts
}

\begin{abstract}
The mill rynd or bridge is probably the most important fitting in a corn mill: it carries the upper millstone on the head of the spindle and enables it to be turned by the machinery of the mill. Although it is therefore an essential component of milling technology, its development has received little attention or analysis. This paper considers the development of the rynd from the earliest power-driven millstones in the Roman period through to the introduction of sophisticated forms in the late 18th and early-mid 19th centuries. This development is witnessed not only in the physical survival of mill rynds themselves but also in the negative information found in the shapes of the recesses which were cut in the faces of millstones to locate them. A range of sources, including depictions of rynds in medieval wall paintings and their use as heraldic charges, is also explored.
\end{abstract}

Keywords: rynd, bridge, millstone, British Isles, Roman, medieval, iconography, post-medieval, 19 th century

Martin Watts, Honorary Associate Research Fellow, College of Humanities, University of Exeter, email: M.Watts@exeter.ac.uk

\section{Introduction}

The rynd is an essential component of milling technology, arguably the most important connection in corn milling machinery. With horizontal millstones it is usually the upper stone of a pair which is rotated and the rynd provides the link between the motive power transmitted from the prime mover through a vertical shaft or spindle, with or without gearing, and the millstone itself. This paper sets out to consider the development of the rynd from the earliest power-driven millstones in the Roman period through to the more sophisticated methods of hanging and driving millstones that were introduced in the late 18th and early 19th centuries, before millstones were superseded by roller mills for the production of flour. The majority of examples discussed are from the British Isles but it is hoped that parallels may be drawn which have relevance to other countries. It is considered important that as part of any recording or analysis of millstones, attention is given to the rynd. Even where millstones are broken or fragmentary, evidence of the shape or form of the rynd may survive which can provide clues to use and, perhaps more importantly, some evidence of date.

\section{Definitions}

The rynd, which has a variety of names in English and other languages, is defined as a bar of wood or iron fixed diametrically across the eye (the central opening) of the upper stone of a rotary quern, by which the stone is located and able to be rotated on the spindle. In power-driven millstones the rynd provides the means by which the upper millstone is rotated. By locating the upper stone on the head of the millstone spindle, the rynd also enables the stone to be raised or lowered, an operation known as tentering, in order to adjust the gap between the milling faces and thus control the texture of what is being milled. Sometimes the only evidence of a rynd that survives is negative, in the form of recesses or chases cut into the runner stone, close to the eye, in which it was located. 


\section{Roman rynds}

In his discussion of the Pompeiian type of donkey mill, Moritz $(1958,85)$ noted that 'The rynd is an integral part of rotary stone mills of all ages; for the upper stone has to be held in a position concentric with the lower, but it also needs a hole in its centre through which the grain can feed into the mill. The rynd bridges this hole without filling it completely, and thus provides a centre round which the stone can rotate, while allowing the grain to reach the stones in the right place.' A single iron spindle was found at Pompeii, together with an iron disc which had a hole through its centre for the spindle and four smaller holes towards its periphery for the grain to flow through (Moritz 1958, 85). Early rynds therefore had a dual function, to keep the upper stone concentric with the lower and to act as a feed control. With regard to the first function, Moritz considered that keeping the stones concentric during grinding was more important for flat or nearly flat stones as against the conical Pompeiian type, although 'even with a steeply conical mill[stone] a rynd-and-spindle arrangement was... desirable; with flatter stones it became indispensable.' (Moritz 1958, 117). There does not appear to have been any easy facility for raising and lowering the rotating upper stones of Pompeiian-type mills to alter or control the texture of the meal, however and, while the spindle and disc would have kept the upper stone (catillus) concentric, it would not have facilitated raising or lowering the stone, which would have tended to drop lower over the lower stone (meta) as the grinding faces wore through use, a problem considered in some detail by Moritz (1958, 85-8).

After Moritz, the early development of the rynd received little attention or analysis in studies of mills and millstones, a notable exception being Henri Amouric's paper L'anille et les meules (Amouric 1996, 39-47), which discusses some Roman and early medieval European forms and, more recently, Robin and Boyer's analysis of rotary quern rynds from France (Robin \& Boyer 2011, 351-8). The upper millstones which have been found on the early Roman watermill sites such as at Avenches, Switzerland (1st century AD) and Barbegal, Provence, (2nd - early 3rd century AD) had concave grinding faces, the steepness of which would have made fitting a rynd into the grinding face difficult (Castella 1994, 46-62). In order to drive the stones, a crampon-type iron rynd was used, its legs fixed with lead in holes in the back

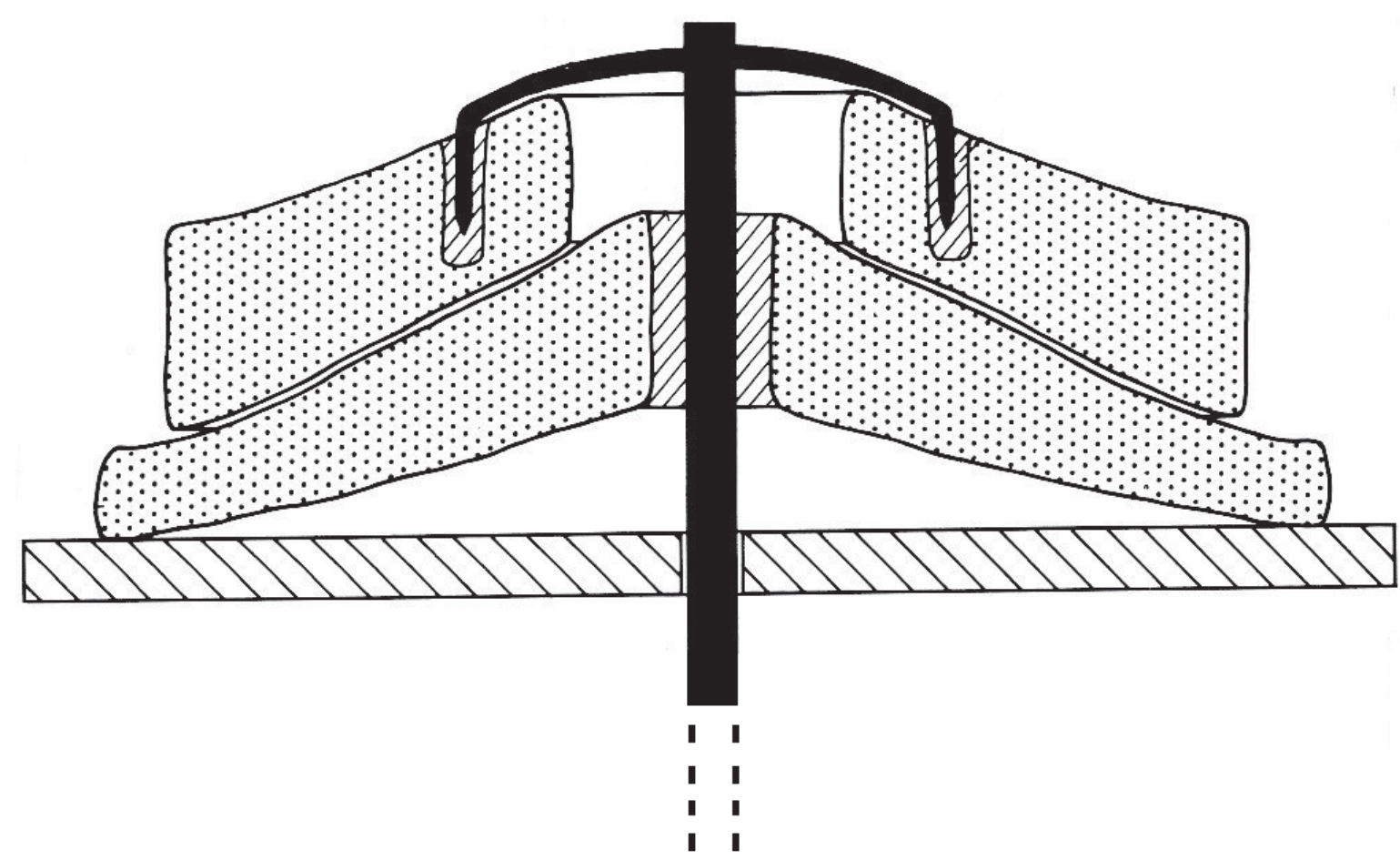

Fig. 1: Roman crampon-type rynd, a reconstruction based on evidence from millstones found during the excavation of a 1st century AD watermill at Avenches, Switzerland (after Castella 1994, fig. 31). 
or upper surface of the stone (Fig. 1). Tentering would have been possible, although the weight of the stone would be taken on the points of the rynd fitting and relied on their physical bond to the stone, rather than the stone being comfortably supported from below, as when the grinding faces became flatter in the later Roman period. Moritz (1958, 107) considered that millstones with flatter grinding faces were more highly developed than the conical form and millstones from datable contexts indicate that flatter stones were in widespread use by the 3 rd century AD. Millstones of both small and large diameter with flat grinding faces were found at the Roman fort site at Saalburg in Germany. The smaller stones had straight flat iron rynds fitted into their backs and it has been presumed that they were therefore not driven from below. Examples of querns with rynds fixed with lead into the backs or upper surfaces of the top stones have also been found, such as at the legionary fortress at Caerleon, in South Wales (Watts 2002, plate 4). The larger Saalburg stones had two dovetail-shaped recesses cut into the grinding face diametrically opposite each other and two millstone spindles complete with dovetail-ended rynds were recovered from the limes fort at Zugmantel, to the west of Saalburg. The millstones and spindles are presumed to date from before 260-270 AD, when the limes forts were abandoned (Jacobi 1914, 89).

A lava runner stone found in the river Walbrook in London in 1955 has two $7 \mathrm{~cm}$ square chases cut into its concave grinding face. The stone, which is now in the Museum of London, is considered to date from the 1st or 2 nd century AD (Marsden 1980, 72). The use of a straight bar rynd is implied, the arms of which must have been angled downwards to allow for concavity of stone. The sole example of a Roman rynd found complete with its spindle in Britain is from a hoard of ironwork found at Great Chesterford, Essex (discussed and illustrated in Watts 2011, 84-5); it has three arms which are angled to fit into the grinding face of a concave millstone. It is perhaps worthy of note that no Roman millstone or quern with three rynd chases has as yet been positively identified in Britain. The Great Chesterford rynd and spindle are dated only by their deposition contexts, thought to be early 5th century AD (Neville 1856, 9-10).

In Britain a number of upper stones have been found which have flat grinding faces and circular eyes with oval or triangular perforations diametrically opposite each other, on both sides of the central eye. Complete examples have been found reused in secondary contexts at Chew Park, Stowey Sutton, Somerset (Rahtz and Greenfield 1977, plate XXVb) and Woolaston, Gloucestershire (Scott Garrett 1938, plate IIb) (Fig. 2). It has been suggested that these perforations acted as feed holes (Baatz 2010; discussed by Cruse, this volume), which would be necessary if the central eye was filled with a some form of fitting such as a wooden plug which could have acted as a rynd. Exactly how these stones were driven (and what drove them) and how they might have been tentered are topics for further comparative research, creative argument and experiment.

It is worth commenting here that Vitruvius's original description of waterwheels and water-mills (in De Architectura, Book X, Chapter V, see Morgan 1960, 294-5) does not mention or describe a rynd (contra Peacock 2013, 105-6; Coutant 2012, 58). Bennett and Elton (1899, 33-4), among others, cite the Latin text and a translation from a mid-16th century edition of De Architectura which contains the following enlargement:

Connected with this tympanum is a larger one, $D$, toothed and placed horizontally, and containing an axis $E$, at the top of which is an iron mortice $F$, which is inserted in the millstone marked.

The illustration referred to is a curious combination of a medieval corn mill and a waterlifting wheel (reproduced in Peacock 2013, 106). If such a rynd was used in Vitruvius's time, he does not say so and, as with some other aspects of his description of a water-driven corn mill, there is still room for discussion and interpretation. As Michael Lewis (1997, 46-7) commented, there is a lacuna... where a closer description has been lost of how the stone was mounted and turned'.
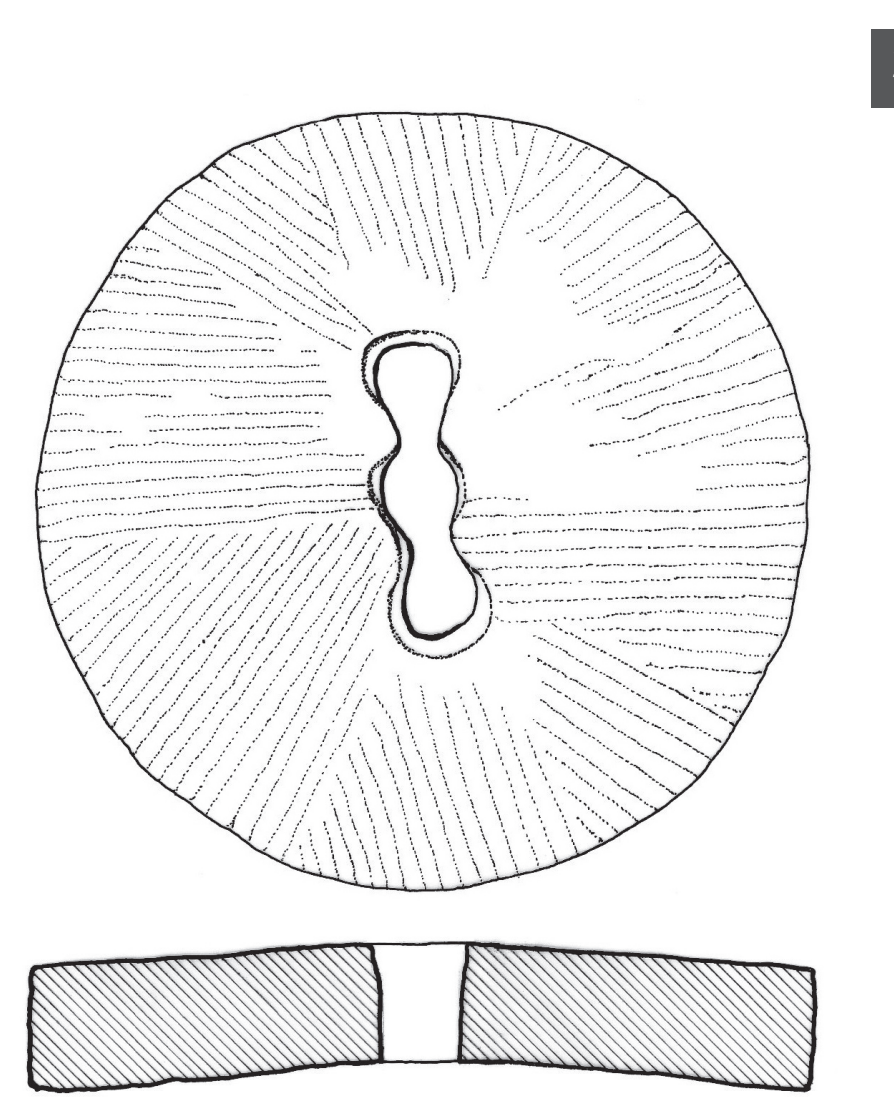

$50 \mathrm{~cm}$

Fig. 2: Roman upper millstone from Woolaston villa, Gloucestershire (drawing by M. Watts). 

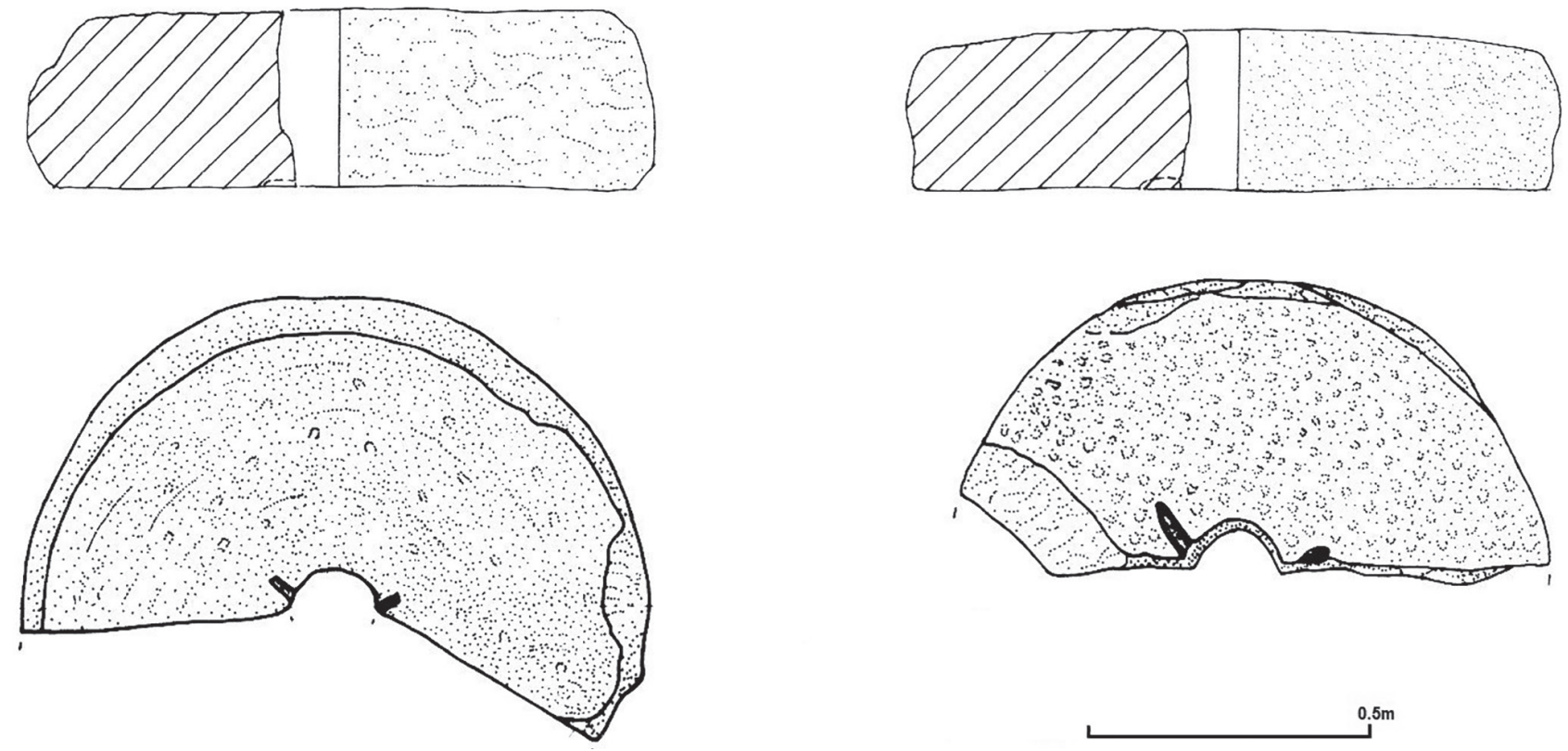

Fig. 3: Millstone Grit upper stones from the 12th century watermill site at Hemington Fields, Leicestershire, showing narrow straight rynd chases (from Clay and Salisbury 1990, fig. 17).

\section{Medieval rynds} evidence of rynds which have been found in England is really too small for detailed analysis. A straight bar, sometimes with dovetail-shaped ends, fitted to the head of an iron spindle does appear to have continued in use, however, from the evidence of millstones from early medieval Ireland and elsewhere in Europe (Rynne 2000, 36-8). The excavation of a 9th century horizontal-wheeled mill at Tamworth, Staffordshire in 1971, recovered over 200 fragments from a possible 26 millstones, only three of which had identifiable evidence of rynds. Two of these were interpreted as 'two-winged', being a flat diametric bar some 24 to $27 \mathrm{~cm}$ long with dovetail-shaped ends. A third incomplete stone had two dovetail-shaped chases at right angles to each other, the even depth of which lead the excavators to be convinced that they represented a single working phase rather than two (Rahtz and Meeson 1992, 76-9). The eye of the stone as reconstructed for display, however, is of very small diameter. If the rynd had four arms, its centre would appear to have occupied most of the eye, leaving little room for grain feed, so this is probably not a practical interpretation. By comparison, two upper millstones recovered from the Gimbsheim boat mill (Germany), which are dated to the 8th century AD, had four dovetailed rynd chases, each opposing pair being of slightly different depths, so clearly indicating two phases of use (Gräf 2006, 142).

The four-armed rynd set in chases cut into the grinding face of the runner stone appears in England by or during the 12th century. Two large fragments of runner stones of Millstone Grit from the mid-12th century mill site excavated at Hemington Fields, Leicestershire have short straight chases, their positions implying a four-armed arrangement. The excavator suggested three arms, however, which remains a possibility (Clay and Salisbury 1990, 295-8). A precedent from Roman Britain has already been mentioned and the use of three-armed rynds in the post-medieval and modern periods is considered further below. The most interesting feature of the rynd chases in the Hemington Fields millstones is that they are quite short and narrow, suggesting that the rynd was a relatively light forging (Fig. 3).

The later medieval form of rynd appears to have been a smith-forged iron cross with four curved arms radiating from a central boss which had a square or rectangular tapered slot through its centre. This fitted over the tapered head of the millstone spindle, to locate it securely and to enable it to be driven, either from below, the most usual arrangement in a watermill, or from above, as in a windmill. It is likely that the rynd was not a tight fit on the head of the spindle and some wear would certainly have taken place during use, with the millstone being rotated constantly in one direction. Such wear would lead to a slight movement, taking up slack as the millstones started to work, and a metallic clink that would have been audible, albeit intermittently. The medieval word inke for a rynd, which occurs in various spellings in documentary sources from the early 13th century (Latham 1994, 251) and is given as 'origin unknown' in the Oxford English Dictionary, may 


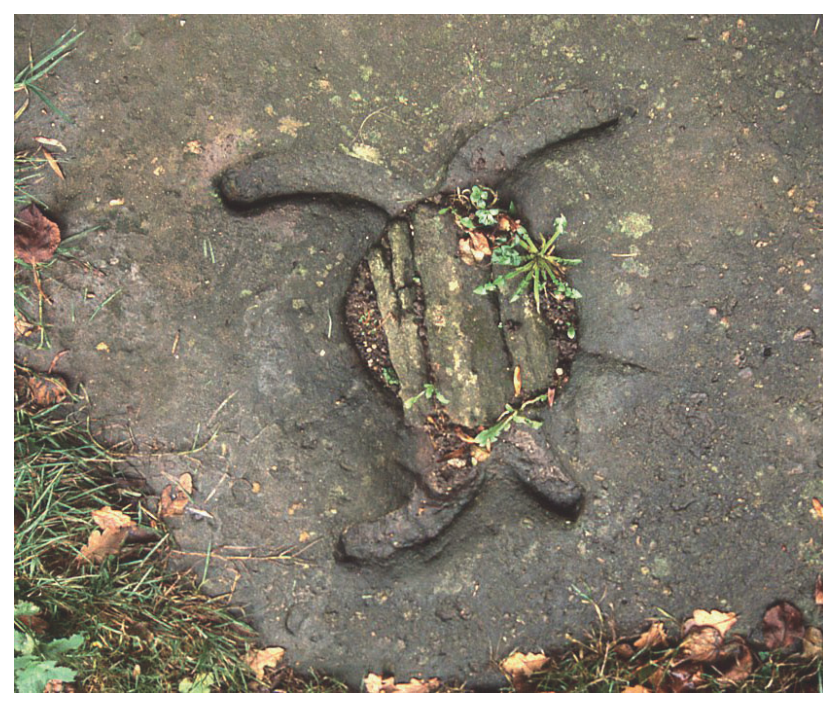

Fig. 4: Reused millstone at Kilcott Mill, Hawkesbury, Gloucestershire, with chases cut for a four-armed rynd, apparently with one broken arm (photo by M. Watts).

therefore be onomatopoeic. The term rynd, again with various spellings, appears in documents from the early 14th century and has continued in use to the present. The word is similar to that found in Germany and the Netherlands. In a late 15th century document referring to the construction of a horse mill at Iden, Sussex a marra and spindle for the mill were made by a smith, the context indicating that marra was the term used for a rynd (Gardiner and Whittick 2011, 104, 235). This medieval Latin word is usually translated as 'hoe' (Fisher 1968, 23), so its use perhaps indicates a dovetail-shaped forging.

There does not seem to have been a standard size or shape for medieval rynds, although a sturdy cross with four curved arms appears to be the most consistent form from the small number of datable medieval millstones and other illustrations. Neither is it clear what the standard practice was of fixing the runner stone on the rynd, if indeed there was one. Some stones appear to have been simply located by the arms of the rynd fitting into individually cut chases and held there by their own weight, as with shelling stones with four-armed rynds used in the post-medieval period (see below). Yves Coutant $(2012,59)$ quotes a late-15th century Flemish documentary source which indicates that the arms of a rynd were fixed into the chases in the stone with small iron wedges. Wooden wedges could also have been used and it is likely that molten lead was also run in to the gap between the iron arms and the stone, as with some Roman examples and as was common practice with rynds and bridges in the 19th century. That the chases were sometimes made to fit a new millstone to an existing rynd appears to be illustrated by a runner stone reused as a step at Kilcott Mill, Hawkesbury, Gloucestershire, where the chases were cut for three and a half arms only (Fig. 4).

\section{Iconography}

As well as the physical evidence for rynds in terms of what can be found from the study of millstones, there are documentary references to their use and repair from the medieval period onwards and also an interesting range of illustrations, including the use of the rynd in heraldry (Bennett and Elton 1899, 232-3). From their origins in the early 12th century, heraldic devices became quickly widespread in western Europe and millstones, mill picks and mill rynds were all used, often as a play on words related to a person's name. Heraldic representations of the fer de moline, cross moline and inke moline are all abstractions, but presumably take reference from known medieval examples of mill rynds. The majority of such illustrations are of rynds with four arms. Parker (1894, 250-1) notes that 'Perhaps no charge has a greater diversity of forms found in ancient drawings.' (Fig. 5).

Some of the earliest illustrations of rynds are found in late medieval wall paintings in churches, where they are sometimes depicted amongst a variety of craft tools. One interpretation of the purpose of these paintings, referred to as 'Christ of the Trades' or 'Sabbath breakers', is that they were intended to teach that by using tools of trade on the Sabbath - which included the working of mills - injury is inflicted on the body of Christ and the user is condemned to perdition (Rouse 1991, 68). An early 15 th century example in the church

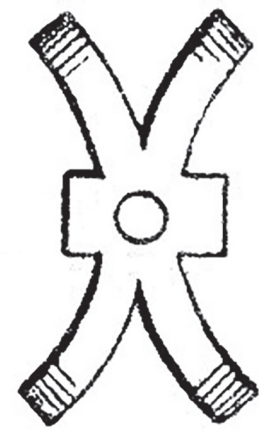

1

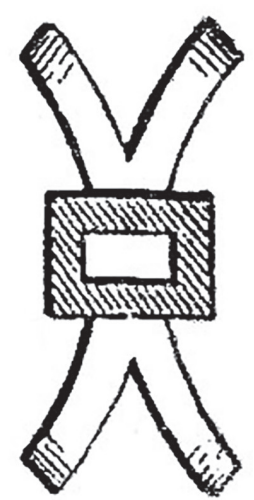

2

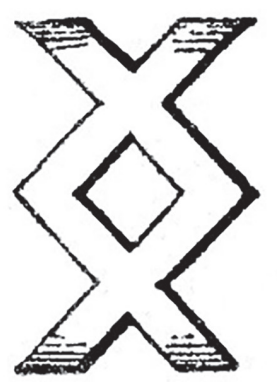

3

Fig. 5: Rynds - fer de moline or ink moline - as used in heraldic devices (from Parker 1894, 250). 
of St Andrew, at Nether Wallop, Hampshire, shows a rynd with four curved arms and a central square slot, which would have fitted over the head of the millstone spindle (Fig. 6).

\section{Post-medieval rynds}

Disused millstones are sometimes found with more than one set of rynd chases, indicating different phases of use. The example illustrated, from a mill site at Uffington, Shropshire (Fig. 7) has two sets of chases, for four curved arms and four straight arms. The available evidence suggests that the curved arm form is the earlier, but when or where the transition to straight arms happened is not clear, due to a lack of dated or datable examples. Both forms continued to be used in the 18 th century, although it is possible that the straight-armed form became more dominant later in that century when rynds began to be cast from patterns rather than being hand forged. Curved

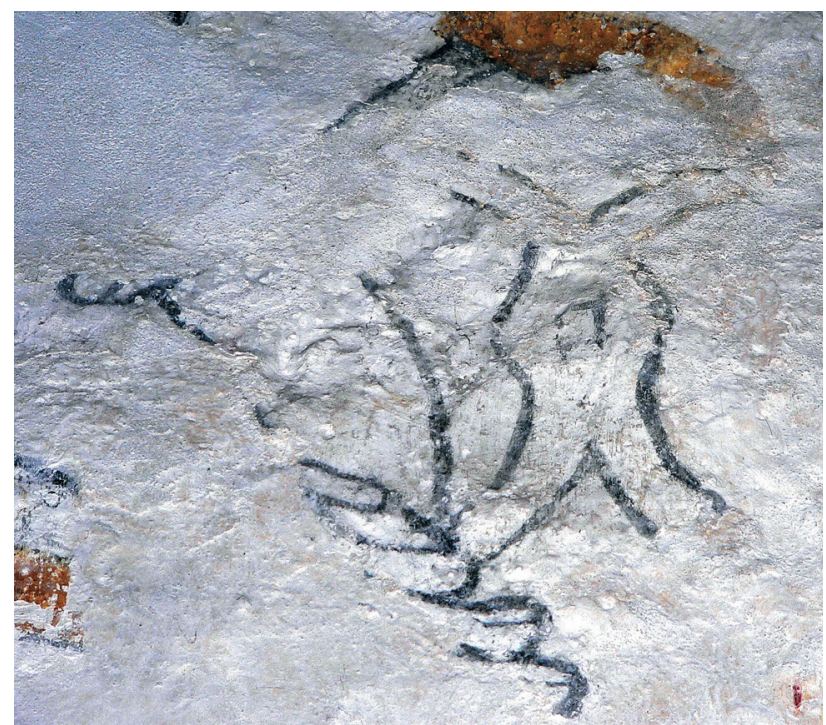

Fig. 6: Rynd depicted on a wall painting of c. 1420 in the church of St Andrew, Nether Wallop, Hampshire (photo by M. Watts). arms are shown on the larger pair of millstones in an engraving of a watermill dating from 1723 (Desaguliers 1744, plate 32, reproduced in Watts 2002, 121), while straight arms appear in an illustration first published in 1760 (Ferguson 1784, plate 7, fig. 3) (Fig. 8). By the time of the sixth edition of Ferguson's book in 1784 his description of a water-powered corn mill is certainly backward-looking in terms of technology, although it clearly describes the setting up of a the rynd:

The top part of the spindle above the bush is square, and goes into a square hole in a strong iron cross... called the rynd; under which, and close to the bush, is a round piece of thick leather upon the spindle, which it turns round at the same time as it does the rynd.

The leather washer also apparently aided the feed of grain into the stones. Ferguson continues:

The rynd is let into grooves in the under surface of the running millstone... and so turns it round in

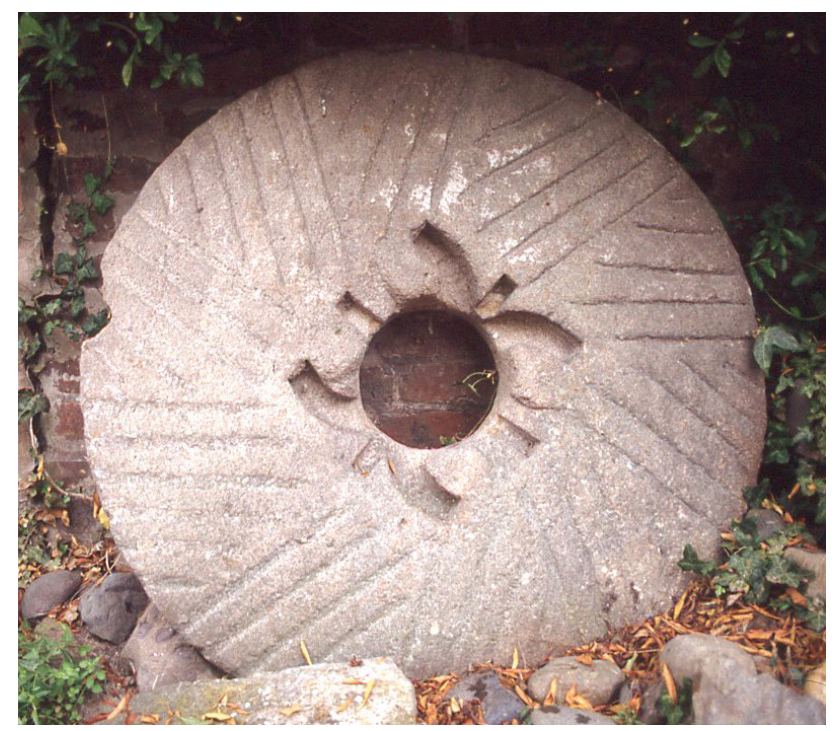

Fig. 7: Millstone with two phases of chases cut for curved four-armed and straight four-armed rynds, Uffington, Shropshire (courtesy of Alan Stoyel).

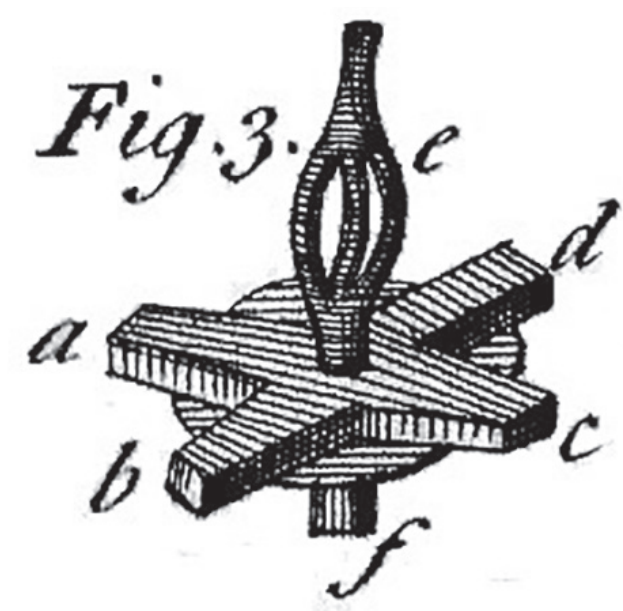

Fig. 8: 18th century stiff rynd: $\mathrm{a}, \mathrm{b}, \mathrm{c}, \mathrm{d}$ are the arms, e the damsel and $\mathrm{f}$ the millstone spindle (from Ferguson 1784, plate 7). 
the same time that the trundle... is turned round by the cog-wheel... It often happens, that the rynd is a little wrenched in laying down the upper stone upon it [the spindle]; or is made to sink a little lower upon one side of the spindle than the other; and this will cause one edge of the upper stone to drag all around upon the other, whilst the opposite edge will not touch. But this is easily set to rights, by raising the stone a little with a lever, and putting bits of paper, cards, or thin chips, between the rynd and the stone. (Ferguson 1784, 72, 74, 76).

The four-armed rynd, whether curved or straight, is sometimes referred to as the stiff rynd in Britain, as it held the runner stone rigidly on the spindle. As such there would have been no need to balance the stone. The practice of balancing became critical with later forms of rynd that allowed the runner stone to float on the head of the millstone spindle, which are discussed below. Both static and dynamic balance was achieved by adding weights, usually in the form of lead, close to the circumference of the stone, similar to the modern practice of balancing car wheels.

It is apparent that as well as chronological and functional variations, the form of rynd being sometimes related to what the stones were used for grinding, there were also local and regional variations. In west Cornwall, for example, a form of two-armed stiff rynd was used (Unwin 2002, 119-20). Generally in Britain the last use of stiff rynds was to drive millstones for shelling grain, a pre-set parallel gap between the milling faces being required. Four-armed rynds were common on shelling stones in oatmeal mills in upland England, the millstones usually being made of Millstone Grit. The runner stones, often of larger diameter than those used for grinding, simply sit on the arms of the rynd.
In some instances a parallel gap between faces of the stones is precisely set using iron rods which pass vertically through the stone, their lower ends locating on the ends of three of the four arms. These rods are held in lead run into the holes, sometimes threaded so they can be turned with a spanner; others were simply adjusted by tapping them with a hammer (Fig. 9a-b). In Scotland three-armed stiff rynds were common, a form also found in Ireland and Wales, all areas where oats were processed. The term brandard or brandreth which was used for a rynd in the Midlands and North of England in the post-medieval period, is also used for a trivet - a three-legged stand for a cooking vessel or kettle. Scaled-down four-armed stiff rynds were also used in geared hand mills, in which a single pair of small-diameter stones were driven by a pair of gears, to grind grain for domestic use and malt for home brewing (Watts 2002, 140-2).

\section{The 19th century}

By the end of the 18th century the four-armed stiff rynd began to be superseded by the bridge or balance rynd for millstones used for grinding meal and flour. The inventor is apparently unknown, but this form was noted as becoming widespread in the early 19th century. The bridge is usually of cast iron, its arms or horns being leaded into recesses cut diametrically opposite each other across the eye of the runner stone. The runner stone floats on the domed head of the millstone spindle (the cockhead), which locates in a semi-circular recess on the underside of the bridge (Fig. 10). If the stone is built up rather than monolithic, as with the French burr stones found in Britain, careful balancing is necessary to ensure the runner stone does not dip
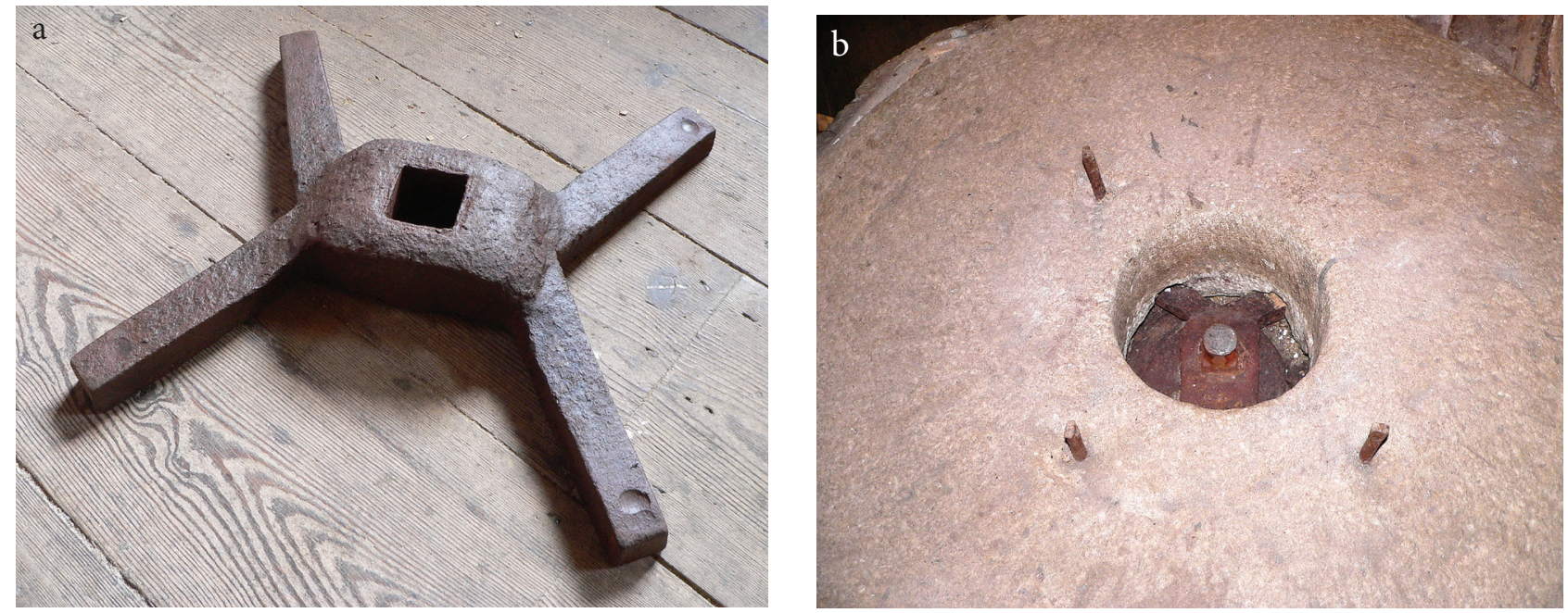

Fig. 9: Rynd on a shelling stone in Heron Mill, Beetham, Cumbria. a shows the rynd - note the indentations on the ends of three of the four arms. b shows the upper millstone on the arms of the rynd, with the three adjusting rods projecting from the back of the stone (photos by M. Watts). 
and rub the bedstone when working. According to the outspoken Yorkshire millwright John Sutcliffe (1816, 262-3), William Pilling of Mirfield, Yorkshire,

... was the first that brought the balance rine [sic] into this neighbourhood; and though not the original inventor, yet I know of none that works it upon so simple and useful a plan.

Sutcliffe's description of the balance rynd is worth citing in detail for the insight it gives into the practical problems of using stiff rynds:

The utility of this simple piece of mechanism is almost, if not altogether, as great as that of the spring shuttle [waterwheel sluice]; for the time and labour that is saved by it is almost incalculable, besides doing its work much better than the fixed rine ever can.

A mill hurst that contained four pair of grinding stones, when the fixed rine was in use, frequently had three pair of them standing while the fourth was hanging, which would frequently require from three to four hours; and often before it has worked an hour, it would have been thrown off the hanging by some hard substance that had got mixed with the grain, which required the same time and labour bestowing upon it again; and after all, it could never be hung anything like so true as by the balance rine.

But with the balance rine they hang themselves; and was a stone thrown off the hanging by something getting under it, the moment it was taken out, the stone would instantly rehang itself without any assistance.

All that time and labour that was wasted in brigging, that is, in setting the spindle upright, is now done away;...

The gain to the miller by the balance rine, when every circumstance connected with it is impartially considered is estimated by many intelligent millers at $1 \mathrm{~s} 6 \mathrm{~d}$ per quarter;... But this supposes the whole of the grain to be ground by the balance rine; but I do not suppose one-fiftieth part of it is, for few millers know of it, and still fewer know how to use it; which shews the necessity of making its utility as public as possible. (Sutcliffe 1816, 263-7).

The description of the upper stone being 'thrown off the hanging by some hard substance' appears to indicate that the stone simply sat on the arms of the rynd, rather than it being fixed into the stone. It is of note that Sutcliffe's drawing of the bridge or balance rynd (Fig. 10) is the only one which illustrates his comments on the design and working of corn mills. The form shown is the most common found in English mills, although in some areas bridges are arched rather than square shaped. The square projection on the top of the bridge is to take the foot of the damsel, an iron forging with raps which ensures a steady feed of grain from the hopper and shoe into the eye of the runner stone. Some bridges do not have this projection, the damsel having a forked end which sits over the mace at right angles to the bridge.

By the mid 19th century the gimbal rynd, an improved form of balance rynd, had been developed (Glyn 1879, 136). Again its originator is unknown. It is a form of universal joint, a term first used by Dr Robert Hooke in 1676, although he was not its inventor. In the Netherlands this form is known as the 'Engelse rynd', so presumably it was introduced there from England (van Bussel 1981, 222-3). Two sockets were fitted into the millstone in which two pivots on an independent iron ring were located. The ring itself pivoted on the cylindrical arms of a bridge, at right angles to those located in the stone. The gimbal thus allowed the runner stone to be almost self-aligning, like a ship's compass, although careful balancing was required with built-up stones (Fig. 11).

Balancing was made easier by casting three or four pockets for weights into the plaster backs of manufactured millstones close to their circumference. In 1859 Henry Clarke was granted Letters Patent

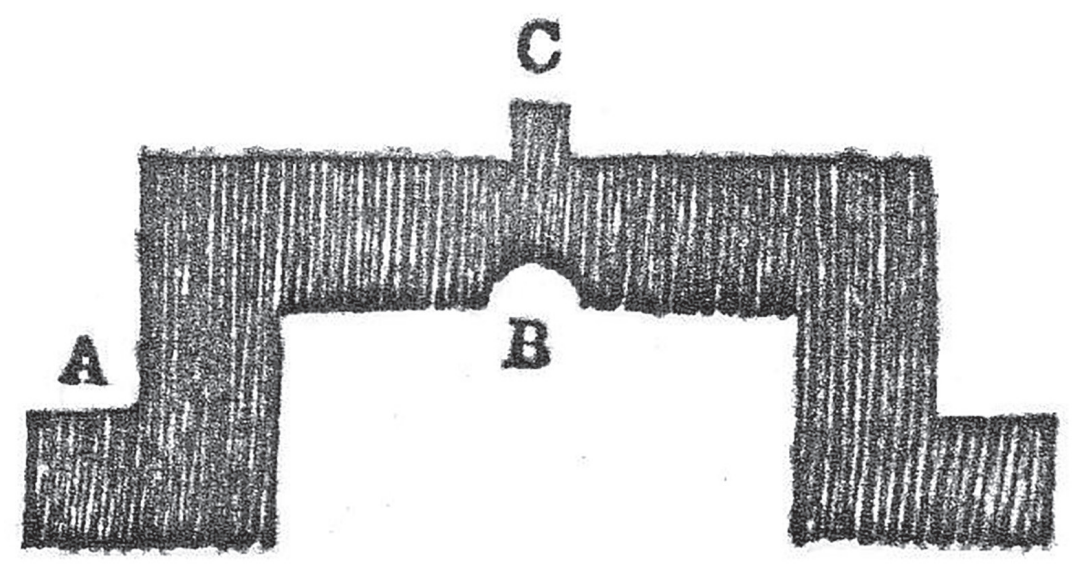

Fig. 10: A bridge or bridge rynd. A is the arm which is fitted into the upper stone; B the dimple which sits on the head of the millstone spindle and $\mathrm{C}$ a square projection over which the foot of the damsel is located (from Sutcliffe 1816, 217). 

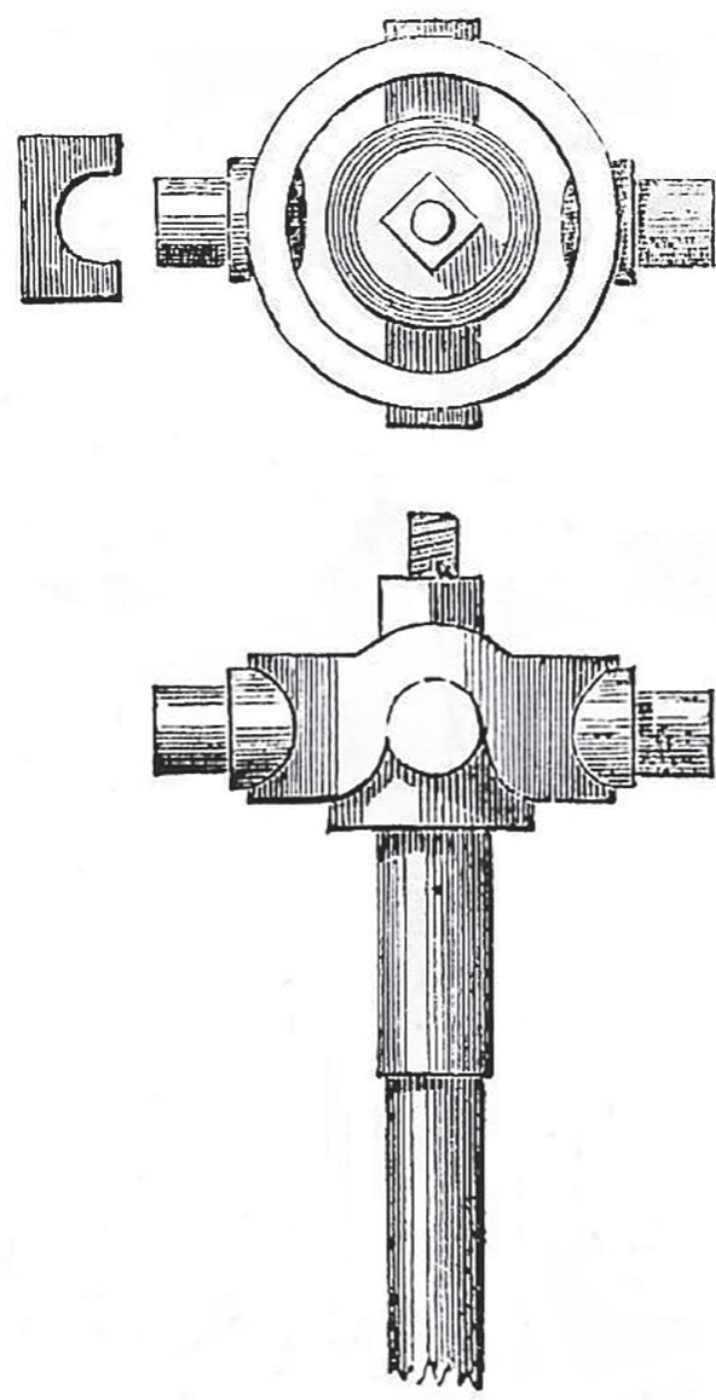

Fig. 11: Gimbal rings or rynd shown in plan (top) and elevation (Glyn 1879, fig. 48).

for an improved method of balancing millstones in the running as well as the standing state, using adjustable weights in circular balance boxes which were built into the plaster backs of French burr millstones during manufacture. This invention appears to have originated in America and was communicated to Clarke by Thomas Narburgh of St Louis, Missouri (British patent number 1182, 11 May, 1859).

The final development has more to do with feeding grain into the millstones than the form of the rynd or bridge itself. This was the result of an amalgamation of design improvements on the traditional form of millstone mill made by the Scottish engineer William Fairbairn. Fairbairn transformed the timber hurst and gearing of a corn mill into iron, setting each pair of millstones, together with its drive and tentering mechanism, on a cast-iron unit called a 'standard'. His designs were developed in the 1830s and the details published in his treatise on Mills and Millwork (Fairbairn 1863). Fairbairn did away with the traditional arrangement where an inclined wooden trough - the shoe - was shaken by a damsel to feed grain from a timber hopper evenly into the eye of the runner stone, replacing it with a small conical metal hopper and an adjustable vertical tube which allowed the grain to run down onto a cupped disc mounted on top of a bridge rynd. The grain flew off tangentially from the cup in ' $a$ beautiful series of curves', according to Fairbairn, who further commended the system's regularity of supply and absence of noise. Fairbairn's system became known as the 'silent feed', but it is of note that it is a rare survival in British millstone mills. Like many 19th century improvements in technology, it was highly engineered and the traditional shoe and damsel arrangement, which could be readily and cheaply maintained by practical millers, persisted to the end of milling with stones.

\section{Bibliography}

Amouric, H. (1997). L'anille et les meules. In: D. Meeks and D. Garcia (eds). Le temps de l'innovation, colloque international: techniques et économies antiques et médiévales (Aix-en-Provence, 1996). Aixen-Provence: 39-47.

BAATZ, D. (2010). Ein Handmühlenläufer aus dem Limeskastell Mainhardt (Kreis Schwäbisch Hall). Fundberichte aus Baden-Württemberg, 31: 607-14.

Bennett, R. and Elton, J. (1899). History of Corn Milling, 2. London and Liverpool.

Castella, D. (1994). Le Moulin Hydaulique GalloRomain d'Avenches 'En Chaplix'. Lausanne.

Clay, P. and Salisbury, C. R. (1990). A Norman mill dam and other sites at Hemington Fields, Castle Donington, Leicestershire. The Archaeological Journal, 147: 276-307.

Coutant, Y. (2012). Windmill Technology in Flanders in the 14th and 15th Centuries 2. The International Molinological Society. Congleton, Cheshire.

Cruse, J. (2014). Roman grinding stones from Northern Britain with two opposed perforations. In: Tilting at Mills, 5th International Colloquium (Almería, Spain, March, 2014).

Desaguliers, J. T. (1744). A Course of Experimental Philosophy, 2. London.

FAIRBAIRN, W. (1863). Mills and Millwork, 2. London.

Ferguson, W. (1784). Lectures on Select Subjects. London.

Fisher, J. L. (1968). A medieval farming glossary of Latin and English words. London.

Gardiner, M. AND WhitTick, C. (2011). Accounts and Records of the Manor of Mote in Iden [Sussex]: 1442-1551, 1673. Sussex Record Society, 92. 
GLyn, J. (1879). Rudimentary Treatise on the Power of Water. London.

GräF, D. (2006). Boat Mills in Europe from Early Medieval to Modern Times. Dresden.

JACOBI, H. (1914). Römische Getreidemühlen. Saalburg Jahrbuch, 3 (1912): 75-95.

LewIS, M. J. T. (1997). Millstone and Hammer. The Origins of Water Power. Hull.

Morgan, M. H. (1960). Vitruvius. The Ten Books on Architecture. New York.

Moritz, L. A. (1958). Grain-Mills and Flour in Classical Antiquity. Oxford.

Neville, R. C. (1856). Roman Antiquities at Great Chesterford, Essex. The Archaeological Journal, 13: 9-10.

PARker, J. (1894). A Glossary of terms used in Heraldry. London.

http://www.heraldsnet.org/saitou/parker/Jpglossa.htm

Peacock, D. (2013). The Stone of Life. Querns, Mills and Flour Production in Europe up to c. AD 500. Southampton.

Rahtz, P. A. AND Greenfield, E. (1977). Excavations at Chew Valley Lake, Somerset. London.

Rahtz, P. And Meeson, R. (1992). An Anglo-Saxon Watermill at Tamworth. London.
Robin, B. AND Boyer, F. (2011). La liaison des meules rotatives manuelles protohistoriques et gallo-romaines: œil et anille. In: O. BuchsENSCHutz, L. Jaccottey, F. Jodry and J.-L. Blanchard (eds). Évolution typologique et technique des meules du Néolithique à l'an mille, Actes des IIIe Rencontres Archéologiques de l'Archéosite gaulois, Aquitania Suppl. 23: 351-8.

Rouse, E.C. (1991). Medieval Wall Paintings. Princes Risborough.

Rynne, C. (2000). Waterpower in Medieval Ireland. In: P. Souatriti (ed.). Working with water in medieval Europe. Leiden, Boston, Köln: 1-50.

Scott Garrett, C. (1938). Chesters Roman Villa, Woolaston, Glos. Archaeologia Cambrensis, 93: 102-25.

Sutcliffe, J. (1816). Treatise on Canals and Reservoirs. Rochdale.

Unwin, A. H. (2002). Some Early Watermill Techniques. Journal of the Trevithick Society, 29: 113-22.

Van Bussel, P. W. E. A. (1981). Korenmolens. Van Ambacht tot Industrie. Eindhoven.

WatTs, M. (2002). The Archaeology of Mills and Milling. Stroud.

Watts, M. (2011). A newly identified milling artefact from Roman Britain. In: D. Williams and D. PEAcock (eds). Bread for the People: The Archaeology of Mills and Milling. Oxford: 93-6. 